\title{
Az egészségnevelés és egészségmegőrzés kiemelkedő gyermek háziorvosa emlékére táblát avattak egykori rendelőjében, Győrött (Dr. Szabó Klára 1943-1991)
}

\author{
A memorial plaque was inaugurated for the outstanding paediatrician of \\ health prevention and health preservation in her former office in Györ \\ (Dr Klára Szabó 1943-1991)
}

Szerző: $\quad$ Schmidt Péter $\triangle$

Egyetemi Oktató Gyermekorvosi Rendelö, Györ

Beküldve: 2018. 05. 21.

doi: $10.24365 /$ ef.v59i3.311

Kulcsszavak: óvodai és iskolai egészségnevelés, prevenció a gyermekfogászati ellátásban, egészségfejlesztés a gyermekkörzeti munkában, emléktábla-avatás, pediátriai szakmai képzésés továbbképzés

Keywords: kindergarten and school health education, prevention in children's dentistry, health promotion in paediatric work, Inauguration of a memorial plaque, paediatric professional training and further education

Dr. Szabó Klára Győr város kiváló gyermek körzeti orvosa volt. A doktornőt 1985. november 17-én ismertem meg, akkor kerültem a Megyei Kórház Gyermekosztályáról a Bacsó Béla úti (jelenleg Tihanyi Árpád úti) gyermekkörzetbe. A váltás hatalmas kihívást jelentett számomra, hiszen eddig - egyetemi gyakorlati éveimet is beszámítva kizárólag klinikán és kórházi osztályon dolgoztam. Szorongással érkeztem a Bacsó Béla úti gyermekkörzeti rendelőbe, ahol óriási tisztelettel és szeretettel fogadott Dr. Szabó Klára gyermekorvos. Elmagyarázta, hogy miért más a körzeti orvosi munka, mint a kórházi osztályos tevékenység; egyben ellátott fontos szakmai tanácsokkal, közvetlen munkatársává fogadott. Ahogy teltek a munkával teli napok, rendelések és tanácsadások, úgy szerettem meg a gyermekkörzeti orvosi munkát.

Az Ady-városi részen mindkettőnk körzetében ekkor, a 80-as évek második felében nagyon sok gyermek született, gondozásuk Klárikával és a védőnőkkel a legnagyobb harmóniában történt. Klubfoglalkozásokba vontuk be a kismamákat, akiket sok esetben váratlanul és felkészületlenül ért, hogy gyermekükkel, azok születése után 3 évig otthon maradhattak, így igyekeztünk aktivizálni őket a közösségi munkába, s ebben Szabó Klára doktornő élen járt. Tevékenyen vett részt az évenként megtartott fogászati hónap egészségnevelési és egészségmegőrzési szakfeladataiban, a körzetében hozzá tartozó óvodákban és iskolákban rendszeresen tartott felvilágosító előadásokat. A kiváló doktornő mind az ünnepekhez kapcsolódó helyettesítéseket, mind a nyári szabadságok elosztását, továbbá az ügyeleti beosztás változásait a legnagyobb megértéssel, korrekt és őszinte módon biztosította.

Dr. Szabó Klára 1943. november 13-án született Vasváron. Iskoláit ott, majd gimnáziumi tanulmányait a pécsi Nagy Lajos Gimnáziumban végezte 1957-től 1961-ig. Ezután felvételt nyert a Pécsi 
Orvostudományi Egyetem Általános Orvostudományi Karára, ahol 1967-ben cum laude minősítéssel szerzett orvos-doktori diplomát. Első munkahelye a pápai kórház Csecsemő- és Gyermek Osztálya volt 1967-1972 között. Csecsemő-gyermekgyógyász szakvizsgáját Pécsett, Kerpel-Fronius Ödön profeszszornál tette le sikerrel, 1971. december 21-én.

1972. március 1-től Győr Ady-városi gyermekorvosi körzet ellátását vállalta. A rendelés a hőskorszaknak számító első időszakban az Ifjúság körút egyik panellakásban múködött, majd megépült a Tihanyi Árpád (egykori nevén Bacsó Béla) úti rendelőintézet, a körzeti gyermekorvosi rendelés itt folytatódott. Dr. Szabó Klára mesterének Méhes Károly professzort tartotta, aki akkor a Győr-Moson-Sopron Megyei Kórház Gyermekosztályát vezette. 1978-ban férjhez ment Vasvári Pál, szakmájában országosan elismert mérnökhöz. 1980-ban született fia, aki követte az orvosi pályán. Dr. Vasvári Gergely kiváló fül-orr-gégész szakorvos, több évi németországi szakmai munka után tért vissza Győrbe, és jelenleg is a Petz Aladár Megyei Oktató Kórház fül-orr gégész szakorvosa. Dr. Szabó Kára állandóan képezte magát, a szakirodalmat folyamatosan követte, tudása naprakész volt. Néhai Fehér János professzor hepatitisszel kapcsolatos országos kutatási munkáiban is aktívan részt vett.

Körzeti orvosi tevékenységünk ideje alatt, a rendszerváltás előtt körzeti - orvosok részére szinte semmiféle képzés - továbbképzés nem volt. Mindenki magára volt utalva, ezért mindig örömmel figyeltük a Magyar Gyermekorvosok Társasága Nyugat-Dunántúli szekciójának évenkénti hagyományos májusi rendezvényeit; Zalaegerszegen, Szombathelyen, Tatán, Veszprémben aktív előadóként folyamatosan beszámolt a körzetében végzett egészségnevelési munkákról, szakmai hozzászólásával, korreferátumával emelte a rendezvény rangját. Ugyanakkor ezek a konferenciák abból a szempontból is fontosak voltak számára, hogy egykori egyetemi társaival, gyermekgyógyász kollégáival személyesen találkozhatott.

1990-ben, sajnos, aggasztó hírek érkeztek egészségi állapotáról. Rosszindulatú alattomos betegsége nap mint nap egyre jobban legyengítette, otthoni kezelését kórházi ápolása követte, közel 30 kg-ra fogyott. Orvosai mindent megtettek érte, de 1991. január 27-én méltósággal viselt, súlyos betegség után hirtelen távozott közülünk.

Dr. Szabó Klára családtagjai személyemet keresték meg kezdeményezésükkel, hogy a rendelő-alapító gyermekorvosnak maradandó alkotás őrizze emlékét a Tihanyi úton, egykori munkahelyén. Ez a kiváló kezdeményezés 2018. április 24-én megvalósult, és a rendelő falán ünnepélyes keretek között felavatták a Doktornő emléktábláját. Erre az ünnepre is vonatkozik Horatius Quintus Flaccus örökérvényű mondása: „Non omnis moriar”, azaz nem halok meg egészen! 